статических алометричних морфопараметров растений Oxycoccus palustris Pers. в четырех фитоценозах Украинского Полесья. Показано, что особи из разных фитоценозов статистически достоверно отличаются между собой величинами практически всех размерных показателей. Установлено, что значения большинства статических метрических морфопараметров у растений Oxycoccus palustris увеличиваются в такой последовательности Экоряда фитоценозов: Betuleto (pubescentis)_Pinetum (sylvestris) vaccinioso (myrtilli)_ sphagnosum (cuspidati) $\rightarrow$ Betuleto (pubescentis)-Pinetum (sylvestris) eriophoroso (vaginati)-sphagnosum (cuspidati) $\rightarrow$ Pinetum (sylvestris) sphagnosum (cuspidati) $\rightarrow$ Sphagnetum (cuspidati) eriophorosum (vaginati). Доказано, что в каждом фитоценозе формируются особи со специфической морфоструктурой. Для исследуемых сообществ установлены характерные морфопризнаки растений Oxycoccus palustris и построены их морфограммы.

Ключевые слова: Oxycoccus palustris Pers., автохтонные дендросозофиты, ценопопуляции, морфометрический анализ, модельные особи, Украинское Полесье.

Sherstuk Maryna. Morphometric Parameters Oxycoccus palustris Pers. in Palustre and Palustre Forest Phytocenoses of Ukrainian Polissya. Has been characterized the magnitude of the 14 static metric and six static alometric indices of morphological parameters of the plant Oxycoccus palustris Pers. in the four phytocenoses within Ukrainian Polissya. Has been shown that individuals from different phytocenoses significantly differ in the values of the absolute majority of size indicators. It is established that the value of static metric morphoparameters Oxycoccus palustris plants grow in the order an ecological series plant communities: Betuleto (pubescentis)-Pinetum (sylvestris) vaccinioso (myrtilli)-sphagnosum (cuspidati) $\rightarrow$ Betuleto (pubescentis)_Pinetum (sylvestris) eriophoroso (vaginati) sphagnosum (cuspidati) $\rightarrow$ Pinetum (sylvestris) sphagnosum (cuspidati) $\rightarrow$ Sphagnetum (cuspidati) eriophorosum (vaginati). Each phytocenosis formed individuals with a specific morphostructures. For the studied communities has been identified specific morfocharacters of Oxycoccus palustris plants and constructed their morfohrams.

Key words: Oxycoccus palustris Pers., autochthonous dendrosozofits, coenopopulations, morphometric analysis, model individuals, Ukrainian Polissya.

Стаття надійшла до редколегії 10.02.2016 p.

УДК 581.5:574.3:502.753 Олексій Холодков

\title{
Історія фітопопуляційних досліджень у широколистяних лісах Сумського геоботанічного округу
}

Повідомляється про історію фітопопуляційних досліджень у широколистяних лісах Сумського геоботанічного округу, що започатковані у 80-х pp. XX ст. й проводилися ботаніками Сумського національного аграрного університету під керівництвом доктора біологічних наук Ю. А. Злобіна (І. Б. Сухим, М. Г. Баштовим, В. І. Троценком, В. Г. Скляр). Серед головних досягнень їхньої наукової діяльності - отримання для досліджуваного регіону грунтовної інформації про стан і динаміку популяцій низки видів судинних рослин, а також апробація та вдосконалення методології комплексного фітопопуляційного аналізу. Об'єкти досліджень - домінанти, співдомінанти й підріст деревних рослин, а також неморальні трави. Пріоритетним напрямом подальших фітопопуляційних досліджень на території округу визначено вивчення рідкісних і зникаючих видів судинних рослин. Ці дослідження в широколистяних лісах регіону розпочато у 2014 р. Об'єктами досліджень стали Allium ursinum L., Lunaria rediviva L. - види, занесені до Червоної книги України, та Corydalis marschalliana Pers., Dentaria quinquefolia M. Bieb., Scilla bifolia L. - види, уключені до Списку рослин і грибів, що підлягають особливій охороні на території Сумської області.

Ключові слова: широколистяні ліси, фітопопуляції, Сумський геоботанічний округ, рідкісні та зникаючі види.

Постановка наукової проблеми та її значення. Один із найнебезпечніших проявів глобальної екологічної кризи кінця XX - початку XXI ст., породженої інтенсивною господарською діяльністю й нераціональним природокористуванням, - збіднення біотичного різноманіття. Останнє є основою нормального функціонування й підтримання стабільності природних екосистем і біосфери в цілому, запорукою існування всіх біомів нашої планети. Тому збереження біорізноманіття нині займає центральне місце в проблемі охорони природи [29, 30].

(C) Холодков О., 2016 
Особливого значення в проблемі щодо біорізноманіття надало дослідженню та збереженню фіторізноманіття на популяційному рівні, без якого неможливе нормальне існування всієї біоти. Популяції рослин $є$ реальними формами існування їх видів, і численні процеси, що відбуваються як на рівні особин, так і у фітоценозах, і в біосфері в цілому, ініціюються, а часто й визначаються закономірностями популяційного життя рослин [13].

Аналіз досліджень цієї проблеми. Популяційні дослідження рослин на Сумщині розпочато у 80-ті pp. XX ст. й проведено під керівництвом доктора біологічних наук Ю. А. Злобіна, який у 1980 р. очолив кафедру ботаніки на той час Сумської філії Харківського сільськогосподарського інституту ім. В. В. Докучаєва (згодом - Сумський сільськогосподарський інститут, нині - Сумський національний аграрний університет). Дослідження із самого початку були різноплановими, спрямованими на вивчення фітопопуляційних характеристик великої кількості різних за своєю роллю й функціями в рослинних угрупованнях видів деревних і трав'янистих рослин - домінантів, асектаторів, рідкісних видів і таких, що перебувають під загрозою зникнення, а також лікарських рослин, бур'янів агроценозів тощо. Низку важливих досліджень проведено й на території Сумського геоботанічного округу $[2,3,4,5,21,22,23,24]$.

Мета й завдання статті - проведення аналізу даних про історію та сучасний стан фітопопуляційних досліджень на території Сумського геоботанічного округу.

Виклад основного матеріалу й обгрунтування отриманих результатів дослідження. Сумський геоботанічний округ Середньоруської лісостепової підпровінції Східноєвропейської лісостепової провінції Лісостепової підобласті Євразійської степової області є округом кленово-липоводубових, дубових лісів і лучних степів $[7,12]$. Його територія розміщена за східною межею поширення максимального (Дніпровського) зледеніння й входить до складу Сумської фізико-географічної області західних відрогів Середньоросійської височини [6]. У минулому на більшій частині території округу (Краснопільсько-Тростянецький геоботанічний район) переважали ліси, суцільні масиви яких зосереджувались у басейнах Псла та Ворскли. Широколистяні ліси (кленово-липово-дубові, липоводубові й дубові) 3 домінантами Quercus robur L., Fraxinus excelsior L. та 3 співдомінантами 3 Acer platanoides L. i Tilia cordata Mill., що займали плакорні простори, на певній площі збереглися тут і понині $[7,17,28]$. Характерна особливість цих лісів, зокрема на території Великочернетчинського геоботанічного підрайону, - наявність у рослинному покриві реліктових рослин - Allium ursinum, Lunaria rediviva, Matteuccia struthiopteris (L.) Tod., Stellaria nemorum L., інших рідкісних і зникаючих видів, у тому числі з диз'юнктивним ареалом, таких, що ростуть на межі ареалу й передусім потребують охорони $[7,10,11,17,28]$.

Об'єктами перших популяційних досліджень у Сумському геоботанічному окрузі, як і в цілому на Сумщині, стали рослини широколистяних лісів, а першим дослідником популяцій рослин на території Сумського геоботанічного округу був І. Б. Сухий, який із 1982 р. займався вивченням ценопопуляцій таких компонентів трав'яного ярусу широколистяних лісів, як Aegopodium podagraria L., Asarum europeum L., Mercurialis perennis L., Polygonatum multiflorum (L.) All., Urtica dioica L., a також підросту деревних рослин, зокрема Acer campestre L., Acer platanoides, Fraxinus excelsior, Tilia cordata. Їхні результати узагальнено в кандидатській дисертації «Дифференциация ценопопуляций растений в широколиственных лесах Среднерусской возвышенности (Украинская ССР)», захищеній у 1986 р. [23], а також у наукових статтях [2, 3].

Із 1988 р. вивченням структури та закономірностей існування ценопопуляцій трав'янистих рослин широколистяних лісів в умовах рекреаційних навантажень займається М. Г. Баштовий. Об'єктами дослідження стали ценопопуляції типових лісових трав - Aegopodium podagraria, Mercurialis perennis, Polygonatum multiflorum. [2, 3, 4, 5]. Із 1990 р. В. І. Троценко вивчає популяції, їхню структуру та запаси лікарської рослини Origanum vulgare L., розробляе рекомендації з їі раціонального використання [24]. В. Г. Скляр із 1995 р. досліджує структуру, стан і механізми природного відновлення популяцій деревних рослин (Quercus robur, Fraxinus excelsior, Acer platanoides) [21, 22].

Наявні наукові напрацювання чітко засвідчують, що фітопопуляційні дослідження важливі та перспективні. Вони розкривають закономірності популяційної організації рослинного світу, тим самим сприяючи визначенню шляхів й ефективних механізмів збереження фіторізноманіття. Насамперд це стосується рідкісних і зникаючих видів, що часто перебувають у критичному стані, за яким відбуваються незворотня деградація та зникнення популяції цього виду [13]. 
Нині на території Сумського геоботанічного округу проводяться й стають усе більш пріоритетним напрямом популяційні дослідження рідкісних і зникаючих видів рослин з оцінкою стану їхніх популяцій, з'ясуванням особливостей динаміки для розробки й упровадження дієвих природоохоронних заходів. У межах округу відзначено 47 видів судинних рослин, занесених до Червоної книги України, при загальній кількості виявлених на Сумщині 88 видів судинних рослин із Червоної книги $[14,15,16,19,27]$. Зі 123 видів судинних рослин, занесених до Списку рослин і грибів, що підлягають особливій охороні на території Сумської області, 73 знайдено на території Сумського геоботанічного округу $[1,9,15,16,19,20]$.

У широколистяних лісах Сумського геоботанічного округу виявлено оселища 11 видів рослин, занесених до Червоної книги України, зокрема Allium ursinum, Botrychium lunaria (L.) Sw., B. multifidum (S. G. Gmel.) Rupr., Epipactis helleborine (L.) Grantz., Lilium martagon L., Listera ovata (L.) R. Br., Lunaria rediviva, Neottia nidus avis Rich., Platanthera bifolia (L.) Rich., P. chlorantha (Cust.) Reichenb., Tulipa quercetorum, а також 10 видів, уключених до регіонального Червоного списку Сумської адміністративної області - Carex rhizina Blytt ex Lindbl., Carpinus betulus L., Clematis recta L., Corydalis intermedia (L.) Mérat, C. marschalliana, Dentaria quinquefolia, Matteuccia struthiopteris, Pyrethrum corymbosum (L.) Scop., Scilla bifolia, Stellaria nemorum [9, 14, 15, 16, 19, 20]. Проте популяційних досліджень цих видів у широколистяних лісах округу до останнього часу не проводили.

Із 2014 р. нами проведено популяційні дослідження в широколистяних лісах Сумського геоботанічного округу рідкісних видів рослин із охоронним статусом, зокрема Allium ursinum, Lunaria rediviva, занесених до Червоної книги України [27], та Corydalis marschalliana, Dentaria quinquefolia, Scilla bifolia, занесених до Списку рослин і грибів, що підлягають особливій охороні на території Сумської області $[1,26]$.

Висновки та перспективи подальшого дослідження. Фітопопуляційні дослідження в широколистяних лісах Сумського геоботанічного округу розпочато за ініціативою та під науковим керівництвом доктора біологічних наук Ю. А. Злобіна у 80-х pp. ХХ ст. Їх проводили ботаніки Сумського національного аграрного університету: І. Б. Сухий, М. Г. Баштовий, В. І. Троценко, В. Г. Скляр. Головними їхніми здобутками щодо вивчення домінант, співдомінант і підросту деревних рослин та неморальних трав стало отримання для досліджуваного регіону грунтовної інформації про стан і динаміку популяцій низки видів судинних рослин, а також проведення апробації та вдосконалення методології комплексного фітопопуляційного аналізу. У подальшому пріоритетним напрямом фітопопуляційних досліджень на території округу визначено вивчення рідкісних і зникаючих видів судинних рослин, які й розпочато нами у 2014 р. Об'єктами досліджень стали Allium ursinum та Lunaria rediviva - види, що занесені до Червоної книги України, та Corydalis marschalliana, Dentaria quinquefolia, Scilla bifolia - види, уключені до Списку рослин і грибів, що підлягають особливій охороні на території Сумської області. Результатом цих досліджень повинна стати розробка дієвих заходів зі збереження й захисту цих видів на основі методів комп'ютерного моделювання та побудови прогнозів стану популяцій цих рослин в умовах природного середовища, що безперервно змінюється.

\section{Докерела та література}

1. Андрієнко Т. Л. Офіційні переліки регіонально рідкісних рослин адміністративних територій України / Т. Л. Андрієнко, М. М. Перегрим. - К. : Альтерпрес., 2012. - 148 с.

2. Баштовой Н. Г. Виталитетная структура ценопопуляций травянистых растений в условиях антропогенных нагрузок / Н. Г. Баштовой, И. Б. Сухой // Проблемы экологического воспитания населения Сумщины. - Сумы, 1989. - С. 51-53.

3. Баштовой Н. Г. Семенная продуктивность неморальных трав в условиях рекреации / Н. Г. Баштовой, И. Б. Сухой // Проблемы исследований рационального использования природных ресурсов Сумщины и их изучение в школе : материалы Сумской обл. науч.-практ. конф. (13-14 ноября 1990 г., Сумы). Ч. 1. - Сумы, 1990. - С. 77-82.

4. Баштовой Н. Г. Ценопопуляции травянистых растений широколиственных лесов в условиях рекреационных загрузок : автореф. дис. ... канд. биол. наук : 03.00.05 «ботаніка» / Николай Григорьевич Баштовой ; Ин-т ботаники им. М. Г. Холодного НАНУ. - Киев, 1992. -24 с.

5. Баштовий М. Г. Біорізноманіття та біопродуктивність ценотичних популяцій неморальних трав в урбанізованих екосистемах Сумської області / М. Г. Баштовий // Популяційна екологія рослин: сучасний 
стан, точки росту : зб. наук. пр. за матеріалами міжнар. інтернет-симпозіуму, м. Суми, 2-4 квіт. 2012 р. Суми : СНАУ, 2012. - С. 326-333.

6. Виленкин В. Л. Сумская лесостепная область западных отрогов Среднерусской возвышенности / В. Л. Виленкин, В. Н. Никитин // Физико-географическое районирование Украинской ССР. - Киев : Изд-во Киев. ун-та, 1968. - С. 333-348.

7. Геоботанічне районування Української РСР / [Т. Л. Андрієнко, Г. І. Білик, Є. М. Брадіс та ін.]. - К. : Наук. думка, 1977. - 304 с.

8. Гончаренко I. В. Флористичне та фітоценотичне різноманіття північно-східної частини Лісостепу України (Сумський геоботанічний округ) : автореф. дис. ... канд. біол. наук : спец. 03.00 .05 «ботаніка» / Ігор Вікторович Гончаренко ; Ін-т ботаніки ім. М. Г. Холодного НАНУ . - К., 2001. - 20 с.

9. Гончаренко І. В. Аналіз рослинного покриву північно-східної частини Лісостепу України / I. В. Гончаренко. - К. : Фітосоціоцентр, 2003. - 203 с.

10. Гринь Ф. О. Рефугіум міжльодовикових реліктів на Сумщині / Ф. О. Гринь / Укр. ботан. журн. - 1957. Т. 14, №1. - С. 43-55.

11. Гринь Ф. О. Дубові та широколистяно-дубові ліси / Ф. О. Гринь / Рослинність УРСР. Ліси. - К. : Наук. думка, 1971. - С. 194-325.

12. Дідух Я. П. Геоботанічне районування України та суміжних територій / Я. П. Дідух, Ю. Р. ШелягСосонко / Укр. ботан. журн. - 2003. -Т. 60, № 1. - С. 6-17.

13. Злобин Ю. А. Популяции редких видов растений: теоретические основы и методика изучения / Ю. А. Злобин. - Сумы : Университет. кн., 2013. - 439 с.

14. Карпенко К. К. Рослини, занесені до Червоної книги України, що виявлені на території Сумської області / К. К. Карпенко, О. С. Родінка, А. П. Вакал та ін. // Стан природного середовища та проблеми його охорони на Сумщині. - Кн. 5. - Суми : Джерело, 2001. - 104 с.

15. Карпенко К. К. Поширення, стан збереження та рекомендації щодо охорони рідкісних і зникаючих видів рослин у басейні р. Псел на території Сумського та Краснопільського районів Сумської області / К. К. Карпенко, О. С. Родінка, А. П. Вакал та ін. // Екологічні дослідження річкових басейнів Лівобережної України : зб. наук. пр. (за матеріалами Всеукр. наук.-практ. конф., м. Суми, 11-16 лист. 2002 р.). - Суми : СумДПУ ім. А. С. Макаренка, 2002. - С. 144-149.

16. Карпенко К. К. Рідкісні та зникаючі види рослин у природно-заповідній мережі Сумського геоботанічного округу / К. К. Карпенко, О. С. Родінка, А. П. Вакал та ін. // Роль природно-заповідних територій у підтриманні біорізноманіття : матеріали наук. конф., присвяченої 80-річчю Канівського природного заповідника (9-11 верес. 2003, Канів). - Канів, 2003. - С. 110-111.

17. Клеопов Ю. Д. Анализ флоры широколиственных лесов европейской части СССР / Ю. Д. Клеопов. Киев : Наук. думка, 1990. - 352 с.

18. Мельник В. И. Редкие виды флоры равнинных лесов Украины / В. И. Мельник. - Киев : Фитосоциоцентр, 2000. - 212 с.

19. Панченко С. М. Стан вивченості фіторізноманіття Гетьманського національного природного парку / С. М. Панченко, К. К. Карпенко, А. П. Вакал // Популяційна екологія рослин: сучасний стан, точки росту : зб. наук. пр. за матеріалами міжнар. інтернет-симпозіуму, м. Суми, 2-4 квіт. 2012 р. - Суми : CHAУ, 2012. - C. 352-358.

20. Родінка О. С. Рослини, занесені до Червоного списку Сумської області / О. С. Родінка, К. К. Карпенко, А. П. Вакал // Стан природного середовища та проблеми його охорони на Сумщині. - Суми : ПП Віннниченко М. Д., 2004. - Кн. 6. - Ч. 1.- 120 с.

21. Скляр В. Г. Популяційний аналіз природного відновлення широколистяних порід в умовах північного сходу України : автореф. дис. ... канд. біол. наук : 03.00 .05 «ботаніка» / Вікторія Григорівна Скляр ; Ін-т ботаніки ім. М. Г. Холодного НАНУ. - К., 1999. - 24 с.

22. Скляр В. Г. Оцінка морфологічної структури та життєздатності популяцій дрібного підросту в різних лісорослинних умовах Сумщини / В. Г. Скляр / Біологічні науки : зб. наук. пр. Сумського держ. пед. ун-ту ім. А. С. Макаренка. - Суми : РВВ СДПУ, 1999. - С. 50-57.

23. Сухой И. Б. Дифференциация ценопопуляций растений в широколиственных лесах Среднерусской возвышенности (Украинская ССР) : дис. ... канд. биол. наук : 03.00 .05 / Иван Борисович Сухой. Сумы, 1986. - 289 с.

24. Троценко В. I. Ценопопуляційний аналіз Origanum vulgare L. на Північному Сході України : автореф. дис. ... канд. біол. наук : 03.00.05 «ботаніка» / Троценко Володимир Іванович. - Суми, 1994. - 24 с.

25. Флора УРСР : в 12 т. - К. : Вид-во АН УРСР, 1938-1965. - Т. 1-12.

26. Онтогенетична структура популяцій Corydalis marschalliana (Pall. ex Willd.) Pers. на території Сумського геоботанічного округу / О. В. Холодков / Вісник Черкаського університету. - Серія : Біологічні науки. № 1. -2016 . - C. 111-119. 
27. Червона книга України. Рослинний світ. / за ред. Я. П. Дідуха. - К. : Глобалконсталтинг, 2009. - 900 с.

28. Шеляг-Сосонко Ю. Р. Формація дуба звичайного (Querceta roboris) Лівобережного рельєфного лісостепу України / Ю. Р. Шеляг-Сосонко / Укр. ботан. журн. - 1971. - Т. 28, №3. - С. 356-361.

29. Rands M. R. Biodiversity conservation: challenges beyond 2010 / M. R. Rands, W. M. Adams, L. Bennun et al. // Sience. - 2010. - Vol. 329, № 10 - P. 1298-1424.

30. Raven P. H. Introduction to special issue on biodiversity / P. H. Raven, J. M. Chase, J. C. Pires // Amer. J. Bot. 2011. - Vol. 98, №. 3. - P.333-335.

Холодков Алексей. История фитопопуляционных исследований в широколиственных лесах Сумского геоботанического округа. Сообщается об истории фитопопуляционных исследований в широколиственных лесах Сумского геоботанического округа, которые начаты в 80-х гг. XX в. и проводились ботаниками Сумского национального аграрного университета под руководством доктора биологических наук Ю. А. Злобина (И. Б. Сухим, М. Г. Баштовым, В. И. Троценко, В. Г. Скляр). Главными достижениями их научной деятельности является получение для исследуемого региона полной информации о состоянии и динамике популяций ряда видов сосудистых растений, а также апробация и совершенствование методологии комплексного фитопопуляционного анализа. Объектами исследований указанных ученых были доминанты, содоминанты и подрост древесных растений, а также неморальные травы. Приоритетным направлением дальнейших фитопопуляционных исследований на территории округа определены изучение редких и исчезающих видов сосудистых растений. Эти исследования в широколиственных лесах региона начаты в 2014. Объектами исследований стали Allium ursinum L., Lunaria rediviva L. - виды, занесенные в Красную книгу Украины, и Corydalis marschalliana Pers., Dentaria quinquefolia M. Bieb., Scilla bifolia L. - виды, которые включены в Список растений и грибов, подлежащих особой охране на территории Сумской области.

Ключевые слова: широколиственные леса, фитопопуляции, Сумской геоботанический округ, редкие и исчезающие виды.

Kholodkov Oleksij. History of Phytopopulation Studies in Deciduous Forests of Sumy Geobotanical Region. This article describes the history of phytopopulation studies in deciduous forests of Sumy geobotanical region. These studies were initiated and carried out by botanists of Sumy National Agrarian University - I. B. Sukhiy, M. G. Bashtoviy, V. I. Trotsenko, V. G. Sklyar under the guidance of Doctor of Biological Science, Professor Y. A. Zlobin since 1980. The main achievement of their research activities was to get detailed information about the status and dynamics of populations of several species of the vascular plants and the validation and improvement of methodology of the complex phytopopulation analysis on the research area. The objects of research these scientists were dominants, codominants and regrowth of woody plants and nemoral herbs. The priority of the further research was identified rare and endangered species of vascular plants on the research area. These researches were begun in 2014 in the deciduous forests in the Sumy geobotanical district. Allium ursinum L., Lunaria rediviva L.became the subject of studies. This plants were listed in the Red Book of Ukraine. Also Corydalis marschalliana Pers., Dentaria quinquefolia M. Bieb., Scilla bifolia L. were listed in the List of plants and mushrooms belonging to the special protection on the territory of Sumy region became the subject of studies.

Key words: deciduous forests, phytopopulations, Sumy geobotanical district, rare and endangered species.

Стаття надійшла до редколегії 29.03.2016 p. 